\title{
Legal Reform: China's Law-Stability Paradox
}

\author{
Benjamin L. Liebman
}

\begin{abstract}
In the 1980s and 1990s, China devoted extensive resources to constructing a legal system, in part in the belief that legal institutions would enhance both stability and regime legitimacy. Why, then, did China's leadership retreat from using law when faced with perceived increases in protests, citizen complaints, and social discontent in the 200os? This law-stability paradox suggests that party-state leaders do not trust legal institutions to play primary roles in addressing many of the most complex issues resulting from China's rapid social transformation. This signifies a retreat not only from legal reform, but also from the rule-based model of authoritarian governance that has contributed much to the resilience of the Chinese system. The law-stability paradox also highlights the difficulties facing efforts by China's new leadership to reinvigorate legal reform.
\end{abstract}

BENJAMIN L. LIEBMAN is the Robert L. Lieff Professor of Law and the Director of the Center for Chinese Legal Studies at Columbia Law School. His recent publications include "Leniency in Chinese Criminal Law? Everyday Justice in Henan," in the Berkeley Journal of International Law (forthcoming 2014); "Malpractice Mobs: Medical Dispute Resolution in China," in the Columbia Law Review (2013); “A Return to Populist Legality? Historical Legacies and Legal Reform," in Mao's Invisible Hand (edited by Sebastian Heilmann and Elizabeth Perry, 2011); and "Toward Competitive Supervision? The Media and the Courts," in The China Quarterly (2011).
D o robust legal institutions support or subvert efforts to maintain social stability in an authoritarian state? Over the past decade, this question has become central to discussions concerning legal reform in China. In the 1980s and 1990s, China devoted extensive resources to constructing a legal system, including training legal professionals, encouraging greater use of the courts, and adopting new laws designed to regulate and constrain state conduct. In the 200os, in contrast, the Chinese party-state's focus shifted toward emphasizing resolution of disputes outside the formal legal system, negotiated outcomes in the formal legal system, flexible application of rules and procedures, and greater oversight of judges and other legal professionals. ${ }^{1}$

This essay focuses on what I refer to as China's law-stability paradox. Having devoted extensive resources to constructing a legal system in the $1980 \mathrm{os}$ and 1990s, why did China's leadership retreat from using law when faced with perceived increases in protests, citizen complaints, and social discontent in the 20oos? China's legal reforms have been designed in part to further stability. Yet party-state 
leaders appear not to trust legal institutions to play primary roles in addressing many of the most complex issues resulting from China's rapid social transformation. The party-state has prioritized rapid resolution of conflict over adherence to legal procedures.

In China, the term social instability is often understood to refer specifically to incidents of protest or social conflict. Yet the phrase has evolved to cover a much broader swath of activity and discourse, including online discussions of high-profile issues and any conduct that the party-state views as a potential threat to its authority or legitimacy, including corruption, group litigation, and virtually any publicly discussed controversial topic. Social instability in China thus refers narrowly to acts of protest and broadly to conduct that party-state officials view as having the potential to create unrest or to challenge the party-state's power.

Evidence from China suggests that top leadership has in recent years perceived adherence to legal rules as a constraint on efforts to maintain social stability. ${ }^{2}$ This approach may be due to concerns that stronger legal institutions could threaten Communist Party control. But recent attitudes toward law also reflect party-state efforts to maintain legitimacy by being responsive to the public, as well as uncertainty about the utility of law in managing a period of rapid change. Law has become an important governance tool in China, but adherence to legal procedures is not a source of party-state legitimacy. Recognizing China's law-stability paradox challenges Western arguments regarding the role legal reforms have played in the construction of China's form of authoritarianism, 3 suggesting a retreat not only from legal reform but also from the rule-based model of authoritarian governance that has contributed much to the resilience of the Chinese system.
The law-stability paradox also highlights Benjamin $L$. the difficulties facing efforts to reinvigo- Liebman rate legal reform. Under the slogan "rule of law China," newly appointed Communist Party General Secretary and President $\mathrm{Xi}$ Jinping has signaled a desire to enhance legal reform and force official actors to obey legal norms. The Communist Party Central Committee's "Resolution on Several Important Issues on Comprehensively Deepening Reform" (or simply, the Third Plenum resolution), issued in November 2013, outlines some potentially important reforms to the legal system. Xi's comments and the resolution have brought cautious optimism to many people working within the Chinese legal system who have viewed policies of the past decade as an assault on legal norms and the idea of rule-based governance. Yet other recent developments, including renewed emphasis on stability and detentions of legal activists, suggest that fundamental changes to official attitudes about the role law plays in China are unlikely. The law-stability paradox suggests that reform requires not only renewed commitment to the use of legal procedures and institutions, but also breaking the cycle of distrust that undermines the authority of legal institutions and rethinking how the party-state conceives of its own legitimacy.

$\mathrm{X}_{\mathrm{i}}$ forms announced following the Third Plenum in November 2013 have been widely viewed as efforts by Xi to mark a clean break from his predecessors, especially following the fall of Bo Xilai, the former Communist Party Secretary of Chongqing whose populist approach was seen by many as a direct assault on rule-based governance. $\mathrm{Xi}$ is not the first Chinese leader to use the rhetoric of law to distinguish himself from his predecessors. Deng Xiaoping's embrace of legal reforms in the late 1970 s 
China's and 1980 s was in significant part a reaction Law- to the chaos and violence of the Cultural Stability Paradox Revolution.

China's legal reforms initially focused on creating a legal framework for economic development. 4 By the 1990s, the focus of new laws expanded to include a range of other issues, from environmental protection and women's rights to administrative laws that facilitate challenges to state action and regulate state conduct. The number of trained legal personnel also expanded rapidly in the 1980 os and 1990s, with the total number of lawyers increasing from 3,000 in 1978 to more than 160,000 by the early 2000 . Professionalization was explicitly encouraged: hundreds of law schools and law departments opened; legal expertise developed within the National People's Congress and other law-drafting bodies; and beginning in 2002, all new judges, procurators, and lawyers were required to hold university degrees and pass a unified national bar exam. ${ }^{5}$ Significant attention was devoted to making the legal system accessible to ordinary people. In the late 1990 os and early 200os, China devoted resources to constructing a state-run legal aid system, and for the first time permitted the development of quasi-independent public interest law organizations. Debate about legal issues also became common in the media in the 1990s, advancing popular knowledge of law.

Although reforms to the legal system in the 1980 os and 1990 s were impressive, abuses continued to be widespread. Many rights set forth in the large volume of new laws went unenforced. The Chinese party-state continued to rely on political campaigns to address the most significant problems - including threats of instability - and to enforce new legal norms. Courts and procurators remained under direct Communist Party oversight. Party political-legal committees and individual party and gov- ernment officials played significant roles in influencing outcomes in court and in resolving disputes outside the formal legal system, reflecting a continuation of revolutionary-era distrust of autonomous institutions. ${ }^{6}$ Populism remained an important factor in shaping legal outcomes. Legal rules were designed primarily to facilitate, not constrain, party-state policy, in particular economic development. Law was not a mechanism for oversight over the party-state itself.

General Secretary Hu Jintao and Premier Wen Jiabao took power in 2003 against a backdrop of rising concerns about social unrest and inequality. They initially appeared to use law to signal a break from the past. Legal scholars and lawyers seized on a perceived new commitment to reform to call for greater enforcement of the constitution and a deepening of legal reform.7 There were some modest successes for advocates of reform, most notably the 2003 abolishment of the custody and repatriation detention system for migrant workers following an outcry from the media and legal academics concerning abuses in the system. The SARS outbreak the same year led to widespread calls for, and apparent new state commitment to, increased government transparency. China also amended its constitution in 2004 to add provisions protecting human rights and private property.

Despite this initial optimism, the 2003$2013 \mathrm{Hu}$-Wen era became known for its deemphasis on legal reform. In the first two decades of legal reform, embrace of law and rule-based governance was largely understood as enhancing the party-state's authority and legitimacy. In the $\mathrm{Hu}$-Wen period, in contrast, the Chinese leadership appeared to develop a more skeptical approach to law. The result was a decade of slowing legal reform and greater party oversight over the legal system, what legal scholar Carl Minzner has called China's 
"turn against law," and what I have elsewhere described as China's "return to populist legality."

New official attitudes toward law in the $\mathrm{Hu}$-Wen era were manifest most clearly in the emphasis on maintaining social stability and constructing a "harmonious society." Stability has been a key concern throughout the reform era. In the 2000 , however, stability attracted renewed attention as reports of protest and unrest mounted. In the 1980s and 1990s, legal reforms were largely thought to promote stability: it was better to have disgruntled citizens suing in court than protesting or burning down government offices. In the 200os, in contrast, official sensitivity to unrest resulted in deemphasis on legal procedures and the creation of incentives for local officials to maintain stability, often at the expense of following legal norms.

In the 200os, courts came under pressure to mediate the majority of civil cases. Courts received explicit targets for mediating percentages of cases; mediation rates in some jurisdictions exceeded 80 percent. 9 This trend marked a shift from the 1990s, when adjudicated outcomes had become the norm in most cases decided by China's courts. Official encouragement of mediation reflected the belief that mediated cases are less likely than adjudicated cases to result in escalation and unrest. Mediation also fit well into official policy of re-embracing revolutionary-era concepts of "justice for the people" and the "Ma Xiwu adjudication method," which emphasized resolving disputes immediately, on the spot, and in line with popular views. ${ }^{10}$

High mediation rates lead to concerns that litigants are being coerced into agreeing to mediated outcomes and denied the opportunity to resolve cases in accordance with the law. In many contentious disputes, mediation is handled through "grand mediation," led by local party Benjamin $L$. leaders, with courts being one of many Liebman actors at the table. Officials and judges serving as mediators often act as fact finders, pressuring parties and their families to agree to settlements.

Many judges view mediation as subverting their proper role and adding to their workload. Yet mediation also protects the courts. Mediated outcomes insulate courts from appellate review and prevent cases from being made public, reducing the possibility that judges will be held accountable for incorrectly decided rulings. In some substantive areas, most notably labor, heavy reliance on mediation outside the courts also reflects the courts' lack of capacity to handle a surge in disputes. ${ }^{11}$

Mediation in the 2000 s extended to administrative cases (where it had previously been banned by the 1989 Administrative Litigation Law) and criminal cases. Equity concerns are particularly apparent in criminal cases. Many defendants in minor criminal cases who agree to compensate their victims receive suspended sentences. Those who do not pay compensation, or are unable to do so, generally receive prison terms. ${ }^{12}$ In more serious cases, compensation payments by defendants or their families to victims can determine whether defendants receive suspended death sentences or life terms rather than the death penalty. The emphasis on compensation and negotiated outcomes in criminal cases reflects resource concerns and official policy of treating minor cases leniently. ${ }^{13}$ Yet the encouragement of settlement and compensation in criminal cases also mirrors state apprehension about escalation and protest. Ensuring victims are compensated reduces the possibility of escalation or protest by victims; reducing sentences minimizes the risk of discontent from defendants' families. But whether negotiated outcomes actually produce stability is 
China's unclear: criminal cases continue to be a Law- primary source of complaints concerning Stability
Paradox the courts, in particular from victims' families suspicious that defendants will avoid punishment through backroom deals.

Concerns about stability also affect how judges interpret and apply the law in cases that are resolved through adjudication. In tort cases, most notably medical disputes, it is routine for judges to adjust outcomes to ensure that aggrieved litigants receive compensation, even when there is no formal legal basis for doing so. Judges adopt flexible interpretations of law in order to ensure that aggrieved persons receive compensation in a range of potentially contentious cases, most notably labor disputes and those involving corporate dissolution and bankruptcy (where layoffs are a risk). ${ }^{14}$ Courts in China are innovative, but innovation often serves to insulate courts and judges from criticism, not increase court authority.

Courts in the $\mathrm{Hu}$-Wen era came under extreme pressure to respond to and prevent protest. The volume of "litigation related" petitions and protests surged in the late 1990 o and early 2000 s. $^{15}$ "Letters and visits offices" exist at all levels of the Chinese state to receive and process complaints from citizens. Many other party and state entities, including the courts, the media, and procuratorates, also have their own letters and visits offices to handle complaints. Thus "litigation related" petitions may be filed with letters and visits offices, with courts, or with letters and visits offices at other party-state organizations. Judges and courts are evaluated and ranked based on the number of complaints filed. Complaints or protests about courts are viewed as evidence that judges have not handled the case correctly regardless of the merits of the complaint.

Petitions about the courts reflect problems in the courts, including corruption and lack of competence. But such com- plaints are also a sign of disconnect between popular use of law and the capacity of the legal system to respond. One common source of complaints, for example, is unenforced decisions. In some cases, however, lack of enforcement results from the inability of a defendant to pay, not from inaction by the courts. Likewise, in contentious cases, most notably land disputes, petitions and protests often result from the fact that courts lack sufficient authority to act.

Courts take extreme steps to eliminate complaints. One response has been greater use of mediation, reflecting the view that mediated cases are less likely to result in protest. But courts also maintain dedicated funds that they use to persuade petitioners to stop petitioning, agree to reopen and rehear previously decided cases in response to complaints, and deploy staff to Beijing to intercept and forcibly return home those who seek to file complaints to authorities in the capital. Compensation and mediation agreements frequently include promises by litigants not to petition. Adherence to legal rules is of secondary importance to eliminating the potential for unrest, with courts adjusting outcomes or pressuring defendants to pay additional sums to plaintiffs in already decided cases. ${ }^{16}$ Although official statistics reported a dramatic drop in the volume of litigation-related petitions filed in the latter half of the 200os, judges report that the pressure they face from petitioners has not declined.

Protest likewise influences cases that never make it to court. Concern about unrest is a key factor influencing settlement decisions in areas such as medical malpractice litigation and labor disputes, where defendants often agree to pay significantly more than legally required in order to head off possible protest and violence. ${ }^{17}$ The threat of violence is real: reports of aggrieved patients or their fami- 
lies attacking doctors have become common, as has the practice of family members leaving the body of the deceased at the hospital (sometimes in the lobby) in protest while negotiations over compensation proceed. Specialized intermediaries now exist in many locations to assist people seeking compensation outside the formal legal system, with professional protestors congregating outside hospitals and specialized debt collectors working in many areas. ${ }^{18}$ Officials have acted quickly to ensure that some of the most sensitive disputes, such as those arising out of the Wenchuan earthquake, the Wenzhou high-speed rail accident, and the melamine-contaminated milk scandal, never make it to court. In all three cases, potential plaintiffs were encouraged or compelled to agree to quick settlements. Courts have also refused to accept cases on a wide range of issues linked to social unrest, such as land disputes. Courts lack authority to accept many sensitive cases and refuse to accept such cases even when they do have the authority.

Scholarship on protest in China, as Ching Kwan Lee notes in her essay in this issue, has identified threats of escalation and group action as key determinants of a protest's success. However, evidence from the legal system shows that courts are at times responsive to individuals who pose little threat of collective action. ${ }^{19}$ The incentives for local officials to stop even individual petitioners suggest that existence of such grievances is perceived as a threat to the party-state's legitimacy.

State concerns about stability and legitimacy are also manifest in official embrace of populism in the legal system and in calls for greater party supervision, in part the result of the perception that courts are an important source of public discontent. The term populism in the Chinese legal system includes a broad range of external factors that affect legal insti- tutions, including traditional and online Benjamin $L$. media as well as collective protests. Liebman Appeals to populism often mix with party efforts to assert oversight over the courts. The blending of populism and party oversight was captured most clearly in the promotion of the "three supremes" by former Supreme People's Court President Wang Shengjun in 2008: the supremacy of the party's business, the supremacy of popular interests, and the supremacy of the constitution and law. Courts in recent years have welcomed greater oversight by people's congresses, have increased roles for laypeople in hearing cases, and have emphasized public opinion in court decisions. Such steps contrast with the modest efforts in the direction of greater professionalism in the legal system in the 1990s. Courts have been encouraged to work together with other party and government entities to mitigate risks of instability. ${ }^{20}$ Judges and procurators are increasingly well trained, but such training does not equip them to resist populist pressure. Nor are they supposed to do so: judges are explicitly incentivized to take account of public opinion.

Official embrace of populism and renewed emphasis on Communist Party oversight of the courts is at times explicitly linked to rejection of foreign models of legal development. Legal education has likewise become increasingly ideological in recent years. ${ }^{21}$ Yet not all recent efforts to emphasize links between the courts and the public are efforts to assert greater party-state oversight. Courts have also taken steps to educate ordinary people about law. Some recent developments, such as court efforts to put opinions online and to make courts more accessible to litigants in rural areas, also suggest that courts may be seeking to use appeals to public opinion and populism to boost their own legitimacy. 
China's Outside the courts, a range of other Law- party-state institutions assumed active Stability
Paradox roles in resolving contentious issues and ordinary disputes in the early 20oos. Stability maintenance work has been coordinated by the Central Commission on Comprehensive Social Management, a joint party and government body that is equal in rank to, but formally exists as a separate entity from, the party's Central Political Legal Committee (PLC). The Stability Maintenance Leadership Small Group also exists at the national level directly under the Standing Committee of the Politburo; it appears to be focused on responding to specific incidents of unrest. Both entities have their work offices within the PLC. This structure of multiple organizations working to address threats to stability is replicated at the provincial and municipal levels, although at the local level stability maintenance offices are often combined with petitioning offices into "stability maintenance centers." 22 The party-state has devoted extensive resources to stability maintenance organizations. Local stability maintenance officials often have extensive roles, including the power to intercept and detain petitioners, pay petitioners to settle grievances, and mediate disputes. ${ }^{23}$ These roles reflect efforts to maintain stability at all costs, as well as unease with allowing the legal system to take on the primary role in resolving threats to stability.

Legal reform did not stop in the $\mathrm{Hu}-$ Wen era; important reforms continued throughout the period. Most involved the development of China's legal hardware: new laws and regulations designed to regulate an increasingly complex society. Important examples include the passage of new Property and Tort Laws and major revisions to China's Criminal Law, Criminal Procedure Law, and juvenile justice system. Changes to the Criminal Law and to court review procedures for capi- tal cases resulted in significant decreases in the frequency of death sentences. If fully implemented, revisions to the Criminal Procedure Law have the potential to make the criminal justice process significantly more fair for criminal defendants. The volume of civil cases in the courts also rose, from 4.8 million in 2003 to 7.2 million in 2011, with most of the increase coming in the latter portion of the $\mathrm{Hu}$-Wen decade. ${ }^{24}$ China now hosts the largest volume of copyright litigation of any country in the world. Expanded public space for legal debate has also meant that most of the issues discussed above are widely debated in China, especially online.

Legal developments in the 2000 s nevertheless suggested that party-state leaders were uncertain about the utility of legal procedures and institutions as mechanisms for addressing perceived threats to stability. Having devoted impressive resources to constructing a legal system in the 1980 os and 1990s, the Chinese partystate retreated from using the system in the face of new social problems in the 200os. Many within China have pointed out that such policies have produced a vicious circle. Incentives for officials encourage responsiveness to threats of unrest. Responsiveness, in turn, encourages others to pursue their grievance outside the legal system, or to nao ting, or cause chaos, in the courtroom. The emphasis on stability has also encouraged new forms of abuses, including the creation of "black jails," privately run detention centers hired by local authorities to intercept and detain those who travel to Beijing to petition or protest. $^{25}$

$\mathrm{W}_{\mathrm{h}}$ stability paradox? Four primary factors have had particular influence. First, the color revolutions in Eastern Europe and Central Asia in the early 20oos and the 
Arab Spring of 2011 appeared to raise concerns at the top of the party-state that legal reforms threatened its authority. The emergence of a dedicated group of "rights lawyers" willing to take on cases that the party-state viewed as sensitive, including representing Falun Gong adherents, political dissidents, and the victims of mass disasters, may have heightened such concerns. The arguments of rights lawyers almost always consist of demands that officials follow the law, not explicit calls for political change. Such arguments were viewed by at least some in the political-legal system as threats to party authority. Yet such trends have limited explanatory power. Legal institutions in China remain under direct party-state oversight and have shown little evidence of developing into "sites of resistance" to authoritarian rule. ${ }^{26}$ Little in the way of credible threats to the party-state emerged from the courts or legal profession. Arguments that legal reform and calls for judicial independence represented foreign attempts to subvert the Chinese system appear largely to have been strategic efforts by conservatives seeking to slow the pace of reform and reassert party-state oversight.

Second, the most controversial trends in the legal system in the 2000 all had roots in China's revolutionary and prerevolutionary past. Recent literature has noted the ways in which China's revolutionary traditions have contributed to regime resilience. ${ }^{27}$ The law-stability paradox is in part the consequence of revolutionary traditions and shows that they may be both a resource and a constraint. Populism, lack of differentiation among legal and nonlegal actors, the importance of petitioning, reliance on political campaigns, and the embrace of flexible interpretations of law all reflect a continuation of traditional Communist Party approaches to governance and law. ${ }^{28}$ Such trends may have been less apparent in the 1990 s Benjamin $L$. when the system embraced professional- Liebman ization, but they have always been present. Faced with a perception of increased instability in the 200os, China's leaders reverted to using approaches to law and governance with which they were familiar. A short-term focus on reducing instability amplified the importance of such approaches.

Third, China's law-stability paradox reflects the party-state's conception of its own legitimacy. The central party-state has linked its legitimacy to outcomes and has perpetuated the idea of central officials being "father and mother officials" who are responsive to the grievances of ordinary people. In so doing, the party-state has created a dynamic in which it believes it must respond to complaints that threaten to escalate into unrest, even when the response violates legal norms. The Chinese party-state is at times over-responsive to individual or group protest. Official intervention transforms private law disputes such as tort or labor cases into negotiations with the state. Official intervention encourages others likewise to seek redress outside the legal system. Law in China operates in the shadow of protest, with legal issues transformed into political questions - the opposite of de Tocqueville's observation about the United States that " [ s] carcely any political question arises ... that is not resolved, sooner or later, into a judicial question." 29 Strengthening the role law plays in regulating Chinese society and citizen-state interactions may require not only boosting legal institutions but altering the ways in which the party-state conceives of its own legitimacy, shifting from a focus on results, responsiveness to individual grievances, and populism to legitimacy based on adherence to legal procedures and norms.

Fourth, official reluctance to commit to greater use of law reflects ambiguity about 
China's whether law is the best tool for managing Law- a society undergoing rapid and unpreceStability
Paradox dented social transformation. This is evident both in the failure to follow laws on the books in complex or sensitive cases and in reliance on nonlegal institutions in a wide range of routine cases. Recent literature on the Western financial crisis has noted the ways in which excessive reliance on formal rules can constrain actors in ways that deepen the crisis. 30 China's leadership may not have explicitly embraced such reasoning; but elements of China's approach to managing instability, in particular the continued desire to be able to move rapidly and flexibly, have parallels to those in the West who argue that excessive reliance on legal rules can at times worsen unstable situations.

Steps taken by China's new leaders in 2013 suggest recognition of the need to refocus the party-state on adherence to legal rules. Most notable among announced reforms have been plans to abolish the widely condemned reeducation through labor detention system and renewed efforts to rein in corruption. The Third Plenum's resolution in November 2013 emphasized the importance of human rights, the constitution, and judicial independence, suggesting a desire to reduce external influence on the courts. The resolution also called for reexamination of the role of court adjudication committees, ${ }^{31}$ expansion of legal aid, greater emphasis on transparency in the courts, elimination of the use of torture, addressing and avoiding wrongful convictions, and reducing the number of crimes subject to the death penalty. The resolution provides only a general framework for reform; nevertheless, it has been interpreted by some within China as signaling renewed commitment to legal reform. There are also serious efforts underway to implement the revised Criminal Procedure Law, which went into effect on January 1, 2013.
There are indications that the state is concerned about curbing some of the worst abuses, in particular when they are committed against ordinary people, not activists. In early 2013, numerous Chinese media accounts highlighted abusive illegal conduct by local officials or those employed by them, including cases of forced abortion, violent conduct by those enforcing relocation and demolition orders on expropriated property, and horrific conditions in reeducation through labor detention facilities. More recently, in late 2013 and early 2014, reports circulated that party officials were investigating former Politburo Standing Committee member Zhou Yongkang, the person most closely associated with the stability-at-all-costs approach of the 20oos. Some view such developments as a sign that party-state leaders are serious about reducing abuses committed in the name of stability, and are committed to greater use of formal legal institutions to address social conflict.

Yet proposed reforms have come alongside renewed focus on stability, reflected most clearly in the announced creation of a new National Security Commission under the direct leadership of Xi Jinping. The exact structure and role of the commission and its relationship to existing institutions remain unclear. It is clear, however, that the new commission reflects continued and deepening commitment to addressing perceived external and internal threats to security and stability.

Proposed legal reforms are not likely to have much significance for individuals the state views as threats. ${ }^{32}$ This has been made apparent by the reemergence of party-state concerns that legal reforms could be used to challenge its authority. Reports have noted bans issued by party officials on the discussion of topics such as "judicial independence" and "constitutionalism" in the media and in universities. 33 A number of prominent legal 
activists were detained in the second half of 2013, most notably legal scholar Xu Zhiyong, who was subsequently sentenced to four years in prison. This crackdown on legal activists suggests that the boundaries of politically permissible activities are shrinking even as party-state leaders call for renewed focus on law. Xi Jinping has also reemphasized the role of Mass Line ideology, suggesting that fundamental changes to the political-legal system are not likely. There are signs that some individuals who formerly would have been sentenced to reeducation through labor are being detained through other forms of arbitrary detention. Although some of the announced reforms have the potential to make the legal system more effective and fair in a range of cases, the party-state's emphasis on "rule of law China" is unlikely to bring fundamental changes to the ways the party-state views and uses law. "Rule of law China" will likely continue to include the explicit embrace of populism, rejection of Western models, and the reliance on a range of legal and nonlegal actors to address social conflict.

C hina's law-stability paradox also highlights the challenges facing any renewed efforts at legal reform. The challenge for any serious efforts to strengthen the role of law in addressing social conflict is not only to realign incentives so that local officials follow legal rules; it is also to convince those most likely to engage in acts of unrest or resistance that the legal system can protect their interests. A growing body of literature provides empirical support for the popular perception that the legal system increasingly serves the interests of the elite. 34 Greater emphasis on populism alone is unlikely to change this perception.

Tensions also remain between new legal rules and popular conceptions of justice. Efforts to adjust law to align with popular views risk creating new inequali- ties and undermining the authority of Benjamin $L$. legal institutions. Recognizing that legal Liebman outcomes sometimes do not align with popular conceptions of justice may be necessary to strengthening the authority of legal institutions and to reducing instability. Yet bridging the divide between new legal norms and popular views may be hard, as evidenced by difficulties in enforcing new provisions in the Criminal Procedure Law. Initial evidence suggests that significant progress is being made in implementing provisions that make it easier for counsel to see their clients and access evidence. 35 Such changes are relatively easy to implement because they require only changing state conduct. Yet it appears that little progress has been made in encouraging or compelling witnesses to appear at trial, which is also required by the new law. ${ }^{36}$ Enforcing such provisions requires not only changing state behavior but also addressing traditional reluctance to become involved in legal disputes, in particular those in which witnesses do not have a stake.

Deepening legal reform also requires breaking the cycles of public distrust that undermine the authority of legal institutions. The party-state continues to rely on party institutions, not the courts, to handle the most pressing problems. Recent efforts to combat corruption, for example, have continued to rely primarily on the Communist Party's Discipline Inspection Commission (DIC), a body that is not subject to any legal oversight and that has extensive powers to investigate and detain suspects. Reliance on such party institutions may reflect doubts about whether the courts have the capacity to address such problems. Such reliance reinforces the secondary role played by legal actors.

Courts are trapped in a similar cycle of popular distrust. Legal institutions often appear weak, lacking the authority to decide contentious cases and unable to 
China's enforce decisions in disputes they do Law- adjudicate. As a result, individuals freStability
Paradox quently seek recourse outside the legal system. Their success in doing so further undermines confidence in legal institutions. The lack of trust from party officials and the public also means that legal institutions are not given the authority to act in ways that might allow them to increase public confidence.

China's new leaders face an environment in which legal reform is both easier and more difficult than in the past. Investment in legal infrastructure over the past three decades has created the institutional capacity to resolve a widening range of disputes through the formal legal process, fostered constituencies pushing for reform from within the legal system, and legitimized debate about legal issues. The Chinese system remains capable of rapid change, in particular in the face of perceived crisis. At the same time, populism has reemerged as an important factor in the legal system, the legal system is increasingly viewed as protecting the interests of the elite, party-state leaders appear unable or unwilling to let the legal system handle the most contentious issues, and there appears to be significant uncertainty about the utility of autonomous legal institutions. Academic literature has long noted a question inherent in efforts to construct authoritarian legality: how far can the legal system develop without challenging authoritarian rule? China has largely avoided this question, in part due to the extensive state oversight of the legal system. Any significant efforts to restart legal reform will make the question central to discussions about the future of law in China.

In contrast to other fields surveyed in this volume such as environmental policy or social policies, few working in the Chinese legal system compare China's system to that of other developing, authoritarian, or post-Communist countries. Chinese legal academics and legal professionals assess China's legal development not with reference to that of post-Communist Russia or even Singapore, but to the legal systems of the United States or Western Europe-albeit often an over-idealized form of Western legality. In some respects, China's legal reforms appear to have been relatively successful when compared to other middle-income countries or to postCommunist countries not tethered to the European Union. China has hundreds of thousands of legal professionals and a system that was almost unimaginable at the beginning of the reform era in 1978 . Yet metrics for evaluating legal development are often elusive and misleading. ${ }^{37}$ The number of laws, legal personnel, or cases tells very little about the overall fairness or effectiveness of the Chinese legal system. Assessing China’s legal system is also difficult because such evaluations vary depending on whose interests are prioritized: those of the state or those of ordinary people. Different legal systems serve different functions, and such functions may change over time within the same country. Placing China's legal development in comparative context highlights the fact that there is no single form of or path to legal development and that nonconvergence with Western models of legality may be as likely as convergence. China's recent experiences also highlight difficulties inherent in using law both to legitimize the state and to constrain state action in an authoritarian state undergoing rapid social transformation.

China's law-stability paradox reflects uncertainty about how best to respond to instability and the difficulty of adapting legal rules to a rapidly changing society. The paradox also reflects the challenge of creating new legal rules and institutions in a political system where legitimacy continues to be based on populist respon- 
siveness and delivery of economic growth. Shifting to a system in which legitimacy is based on adherence to legal rules, not just rhetorical commitment to such rules, may be necessary for resolving the lawstability paradox. Doing so may require changing not only how the Chinese party- Benjamin L. state conceives of the relationship be- Liebman tween law and stability, but also how it conceives of its own role in managing China's social transformation.

\section{ENDNOTES}

Author's Note: I explore many of the issues discussed in this essay in more detail in Benjamin L. Liebman, "China's Law and Stability Paradox," in China's Challenges: The Road Ahead, ed. Jacques deLisle and Avery Goldstein (forthcoming 2014).

1 Carl Minzner, “China’s Turn Against Law,” American Journal of Comparative Law 59 (2011): 935-984; Donald Clarke, “Jiang Ping: China’s Rule of Law is in Full Retreat," China Law Prof Blog, March 2, 2010, http://lawprofessors.typepad.com/china_law_prof_blog/2010/03/ jiang-ping-chinas-rule-of-law-is-in-full-retreat.html ; and Benjamin L. Liebman, "A Return to Populist Legality? Historical Legacies and Legal Reform," in Mao's Invisible Hand, ed. Sebastian Heilmann and Elizabeth J. Perry (Cambridge, Mass. : Harvard University Press, 2011), 269-313.

2 Whether China has actually become less stable is contested. It is clear, however, that China's leadership during the 2000 became increasingly concerned with a perceived rise in instability.

3 Andrew J. Nathan, “Authoritarian Resilience,” Journal of Democracy 14 (2003): 6-17.

4 See my overview of this era in Liebman, "A Return to Populist Legality?"

5 For additional discussion, see Benjamin L. Liebman, "China's Courts : Restricted Reforms," The China Quarterly 191 (September 2007): $620-638$.

6 Chen Xi, "China at the Tipping Point? The Rising Cost of Stability," Journal of Democracy 24 (2013): $57-64$.

7 Keith Hand, "Resolving Constitutional Disputes in Contemporary China," University of Pennsylvania East Asian Law Review 7 (2011): 50 - 159.

8 Minzner, "China’s Turn Against Law”; and Liebman, “A Return to Populist Legality?”

9 Ibid

10 Liebman, “A Return to Populist Legality?”

11 Mary Gallagher, “Changes in the World's Workshop: The Demographic, Social, and Political Factors Behind China's Labor Movement," in Dragon vs. Eagle: The Chinese Economy and U.S.China Relations, ed. Wei-Chiao Chung and Huizhong Zhou (Kalamazoo, Mich. : W.E. Upjohn Institute for Employment Research, 2012), 99-112.

12 Benjamin L. Liebman, "Leniency in Chinese Criminal Law? Everyday Justice in Henan," Berkeley Journal of International Law (forthcoming 2014).

13 Susan Trevaskes, “The Shifting Sands of Punishment in China in the Era of 'Harmonious Society," Law \& Policy 32 (3) (2010): $332-361$.

14 For more on compensation in labor disputes, see Yang Su and He Xin, "Street as Courtroom: State Accommodation of Labor Protests in South China," Law E Society Review 44 (1) (2010): $157-184$.

15 Wang Ying, “Zhuanxingqi de zhongguo fayuan yu xinfang: shesu xinfang wenti shizheng yanjiu" ["Chinese Courts and Petitioning in a Time of Transition: Empirical Research into the Question of Litigation-related Petitioning”], Ph.D. dissertation, Qinghua University 
China's

(2010); and Benjamin L. Liebman, “A Populist Threat to China's Courts?” in Chinese Justice: Civil Dispute Resolution in Contemporary China, ed. Margaret Y. K. Woo and Mary E. Gallagher (Cambridge: Cambridge University Press, 2011), 269-313.

${ }^{16}$ Liebman, “A Populist Threat to China's Courts?”; and Benjamin L. Liebman, "Malpractice Mobs: Medical Dispute Resolution in China,” Columbia Law Review 113 (2013): 181 - 264.

17 Liebman, "Malpractice Mobs.”

18 Ibid.; and Xu Xin, "Falü shifou zhongyao - Laizi Hua'nan de yige minjian shouzhai anli” [ "Is Law Important - A Case Study on Informal Debt Collection in Southern China”], Sociological Studies 1 (2004): $53-63$.

19 One detailed study found that nearly half of all those who went to Beijing to complain about the courts in one northeast municipality received direct benefits from doing so, generally cash or in-kind payments from the local court. See Wang, "Zhuanxingqi de zhongguo fayuan yu xinfang."

${ }^{20}$ Xu Kai and Li Weiao, “The Machinery of Stability Preservation,” Caixin, June 6, 2011, translated to English in Duihua, June 8, 2011, http://www.duihuahrjournal.org/2011/o6/translation -machinery-of-stability.html; see also Benjamin L. Liebman, "China's Law and Stability Paradox," in China's Challenges: The Road Ahead, ed. Jacques deLisle and Avery Goldstein (forthcoming 2014).

21 Carl Minzner, "The Rise and Fall of Chinese Legal Education," Fordham International Law Journal 36 (2) (2012): $335-396$.

${ }^{22}$ For more detail on such organizations, see Liebman, "China's Law and Stability Paradox."

23 Ibid. ; and Xu and Li, "The Machinery of Stability Preservation."

24 China Law Society, Law Yearbook of China (Beijing: China Law Yearbook Press, 2004 - 2012).

25 “Black Jail Industries,” Global Times, March 3, 2013, http://www.globaltimes.cn/content/ 765426.shtml.

26 Tamir Moustafa and Tom Ginsburg, Introduction to Rule by Law: The Politics of Courts in Authoritarian Regimes (Cambridge: Cambridge University Press, 2008), 1-2.

27 Heilmann and Perry, eds., Mao's Invisible Hand.

28 Liebman, “A Return to Populist Legality.”

29 Alexis de Tocqueville, Democracy in America, vol. 1, ed. Phillips Bradley, trans. Henry Reeve (New York: Alfred A. Knopf, 1946), 280.

30 Katharina Pistor, “Towards a Legal Theory of Finance," manuscript draft, 2012.

31 Court adjudication committees generally consist of senior judges and decide sensitive or difficult cases. The practice has been criticized due to the fact that it results in cases being decided by judges who did not participate in the trial.

32 Nor are reforms designed to reduce the role of populism in the legal system: the decision also calls for broadening channels for the "masses" to participate in the judiciary, although it does also say that such participation shall be "in an orderly manner," suggesting perhaps that specific procedures should be created for such popular participation.

33 Raymond Li, “Seven Subjects Off Limits for Teaching, Chinese Universities Told," South China Morning Post, May 11, 2013, http://www.scmp.com/news/china/article/1234453/dont-teach -freedom-press-or-communist-party-mistakes-chinese-academics; and Li Qi and William Wan, "China's Constitution Debate Hits a Sensitive Nerve," The Washington Post, June 3, 2013, http://www.washingtonpost.com/blogs/worldviews/wp/2013/o6/o3/chinas-constitution -debate-hits-a-sensitive-nerve/.

34 Mary E. Gallagher, "Mobilizing the Law in China : Informed Disenchantment and the Development of Legal Consciousness," Law \& Society Review 40 (4) (2006): 783-816; He Xin and 
Yang Su, "Do the 'Haves' Come Out Ahead in Shanghai Courts?" Journal of Empirical Legal Benjamin L. Studies 10 (1) (2013): 120 - 145; and Yuen Yuen Ang and Nan Jia, "Perverse Complementarity: Liebman Political Connections \& Use of Courts among Private Firms in China," The Journal of Politics (posted online May 2013), http://ssrn.com/abstract=2033230.

35 Li Tao, "Xin xingsufa shishi : lüshi huijian zeng 35\%" ["Lawyer Visits Increased 35\% after Implementation of the New Criminal Procedure Law"], Beijing Youth Net, March 18, 2013, http://bjyouth.ynet.com/3.1/1303/18/7892125.html; and Liang Shuang, "Xin xingsufa 'songbang' lüshi huijian dangshiren mengzeng siwu bei” ["Lawyers See Visits Soar by Quadruple or Quintuple with New 'Relaxed' Criminal Procedure Law”], Wuhan Evening, March 13, 2013, http://www.hb.xinhuanet.com/2013-03/13/c_115004008.htm.

36 "Xin xingsufa shishi liangge yue: xin tiaozhan xin bianhua" ["Two Months After Implementation of New Criminal Procedure Law: New Challenges, New Changes"], Renmin Gong'an bao, March 11, 2013, http://shzfzz.eastday.com/node2/zzb/shzfzz/jrgz/node1745/ u1ai284475.html; and Wang Jianjiao, "Tonghai fayuan fanying xin xingsufa shishizhong zai zhengren chuting zuozheng fangmian bubian caozuo" ["Inconveniences in the Implementation of the New Criminal Procedure Law Reflected in the Experiences of Witnesses Testifying in Tonghai Courts"], March 25, 2013, http://www.thfy.gov.cn/show.asp?id=1166.

37 Kevin E. Davis, "What Can the Rule of Law Variable Tell Us about Rule of Law Reforms?" Michigan Journal of International Law 26 (2004): 142-161. 